\title{
Stress-Induced Changes in Testosterone Secretion in Male Rats: Role of Oxidative Stress and Modulation by Antioxidants
}

\author{
Mona Abdullah Al-Damegh \\ Department of Biology, College of Science and Arts, Qassim University, Oniza, KSA \\ Email: dr mona aldamegh@yahoo.com
}

Received 3 February 2014; revised 6 March 2014; accepted 15 March 2014

Copyright (C) 2014 by author and Scientific Research Publishing Inc.

This work is licensed under the Creative Commons Attribution International License (CC BY).

http://creativecommons.org/licenses/by/4.0/

(c) (i) Open Access

\section{Abstract}

Seventy adult male albino rats were randomly allotted into 3 main groups: control group $(n=10)$, acute stress-exposed group $(n=30)$ and chronic stress-exposed group $(n=30)$. Each of the stressed groups was subdivided into 3 equal subgroups $(n=10$ /subgroup, $S G)$ : subgroup 1 animals were exposed to immobilization stress, SG2 animals, were given immobilization stress and supplemented with $\alpha$-tocopherol (vitamin E), SG3 animals were exposed to immobilization stress and supplemented with ascorbic acid (vitamin C). Immobilization stress exposure was applied once for 6 continuous hours in the acute stressed group and was 6 hours daily for 10 consecutive days in the chronic stressed group. In all vitamin supplemented groups, both vitamin $E$ and $C$ were administered orally mixed with the diet in a similar dose of $500 \mathrm{mg} / \mathrm{kg}$ diet. This supplementation started 6 weeks prior to the stress exposure and continued throughout the experimental period. At the end of the last immobilization session, sera were harvested from all animals thereafter, animals were sacrificed and the testes were immediately excised and processed for further biochemical investigations. Serum testosterone and luteinizing hormone levels were measured and the activities of antioxidant enzymes [catalase (CAT) \& glutathione-s-transferase (GST)] as well as malondialdehyde (MDA) concentrations were determined in sera and testes. Compared to control, the results revealed that acute and chronic immobilization stress caused significant decrease in levels of serum testosterone and luteinizing hormone $(\mathrm{LH})$. Also, significant reductions $(\mathrm{P}<0.01)$ were found in the activities of CAT and GST in sera and testes. Contrariwise, there existed a significant $(P<0.05)$ increase in MDA concentrations in serum and testis. Co-administration of vitamin $E$ or $C$ relatively restored $(P<0.01)$ the above parameters. Thus, this study draws a conclusion that immobilization stress of male rats significantly inhibited testosterone secretion and induced oxidative stress which partially mediated this inhibition. It also proved a protective role of vitamin $E$ and $C$ against the oxidative stress-induced down-regulation of testosterone secretion with a better efficacy of vitamin $E$. 


\section{Keywords}

\section{Stress; Rats; Testosterone; LH; Antioxidants; Enzymes}

\section{Introduction}

The vast numbers of studies in both humans and animals confirm the inhibitory role of different stressors in the hormonal function of the testis [1]-[3]. In addition, a variety of mediating mechanisms have been recenthy suggested [3] [4]. However, considerable variations in the response of the hypothalamo-pituitary-gonadal (HPG) axis to stress have been reported. Many stressors decrease LH and consequently, testosterone levels by inhibiting luteinizing hormone-releasing hormone (LHRH) synthesis and release from the hypothalamus [1]. On the other hand, there are stimuli that attenuate testosterone levels without altering LH values in both rodents and humans [5]. Moreover, testosterone level may be increased at initial stages of acute stress with a constant or even decreased LH level [6].

On the other hand, stress exposure has been implicated in the induction of oxidative stress by excessive production of free radicals and reactive oxygen species (ROS), which can cause alterations in both cell membranes and constituents ending by cell mutation or damage [7]-[9].

Testicular membranes are rich in polyunsaturated fatty acids and therefore are susceptible to oxidative stress [10]. In addition, testicular steroidogenic activity is sensitive to free radicals and ROS [11] [12], and a correlation was noted between free radical production and gonadal steroidogenesis [12].

Other studies have drawn increasing attention to the potential for supplementary antioxidants to reduce free radical-induced oxidative stress. Vitamin E and C were shown to be powerful chain - breaking antioxidants that prevent the propagation of free radical reaction and inhibit lipid peroxidation and oxidative damage [13]-[15].

Therefore, present study aimed at examining the role of oxidative stress in mediating the stress-induced changes in testosterone secretion and determining whether the protective effect of the antioxidants (i.e. Vitamin $\mathrm{E}$ and $\mathrm{C}$ ), can modulate such changes.

\section{Materials and Methods}

\subsection{Animals}

Seventy adult male albino rats of relatively similar age and uniform strain weighing around 150 - 170 gm were housed under controlled environmental conditions. Animals were randomly allotted into seven treatments, allowed free access to rat chow pellets and water. Animals were handled daily for one week acclimation period prior to the experimentation.

\subsection{Experimental Design}

Rats were divided into the following three main groups;

1) Control group $(n=10)$ in which animals were under normal managerial condition.

2) Acute stress-exposed group $(n=30)$ in which animals were subdivided into three subgroups $(n=10 /$ subgroup) as follow;

a) Animals were exposed to immobilization stress once for 6 hours (between 08.00 - 14.00 hours).

b) Animals were exposed to immobilization stress and supplemented with vitamin E ( $500 \mathrm{mg} / \mathrm{kg}$ diet).

c) Animals were exposed to immobilization stress and supplemented with vitamin C (500 mg/kg diet).

3) Chronic stress-exposed group $(n=30)$ in which animals were subdivided into three subgroups $(n=10 /$ subgroup) as follow;

a) Animals were exposed to immobilization stress for 6 hours daily (between 08.00 - 14.00 hours) on 10 consecutive days.

b) Animals were exposed to immobilization stress and supplemented with vitamin E (500 mg/kg diet).

c) Animals were exposed to immobilization stress supplemented with vitamin C (500 mg/kg diet).

In all vitamin-treated groups, both vitamin $\mathrm{E}$ and $\mathrm{C}$ were administered orally mixed with the diet in a similar dose of $500 \mathrm{mg} / \mathrm{kg}$ diet [16] [17]. This treatment started 6 weeks prior to the stress exposure and continued 
throughout the experimental period.

\subsection{Stress Procedure}

The immobilization stress model used was technically designed according to Lopez-Calderon et al. [18]. The immobilization units were of local design and consisted of a flexible wire mesh in which the rat was wrapped with its tail extended, then the edges of the wire mesh were curved from both sides to restrict the rat's movement. In addition, the rat's tail was held in place by springs by which the rat was suspended unsupported. Food and water were not allowed during the stress procedure. At the end of the last immobilization session, blood samples were collected from orbital sinus and allowed to clot at room temperature for an hour, centrifuged (4000 rpm/ $10 \mathrm{~min}$ ) and sera were harvested. After blood sampling animals were sacrificed and the testes were immediately excised and processed for biochemical investigations.

\subsection{Assay Procedures}

\section{Testosterone}

Serum testosterone concentrations were determined by an enzyme immunoassay technique according to Trachtenberg [19]. The tracer was horse-radish peroxidase and the chromogen was tetramethyl benzedine (TMB). The intra- and interassay of variations were $6.1 \%$ and $8.3 \%$, respectively.

\subsection{LH}

Serum LH concentrations were measured by IRMA technique according to Santner [20]. This procedure is known as a solid-phase immunoradiometric assay designed for the quantitative measurement of LH in serum and plasma. The tracer used is a radio-labeled polyclonal anti-LH using ${ }^{125} \mathrm{I}$.

\subsection{Catalase and Glutathione-S-Transferase}

Antioxidant enzymes CAT \& GST activities in testes and sera were determined as follow:

Catalase activity was measured by a colorimetric method [21].

Glutathione-s-transferase activity was measured by UV method [22].

Lipid peroxide (malondialdehyde) levels in testes and sera were determined by a colorimetric method according to Ohkawa et al. [23].

\subsection{Statistical Analyses}

Data were analyzed using the student's " $\mathrm{t}$ ” test for unpaired sample. Results were given as means \pm SEM. Probability values (P) less than 0.05 were considered significant [24].

\section{Results}

As shown in Table 1, acute stress caused significant decrease in serum level of testosterone $(49.65 \%, \mathrm{P}<$ $0.0005)$ and LH $(31.57 \%, \mathrm{P}<0.01)$ as compared with the control. Supplementation with either $\alpha$-tocopherol (vitamin E) or ascorbic acid (vitamin C) significantly increased testosterone and LH levels as compared with the stressed group. However, the values still significantly lower than the control group.

Chronic stress caused significant and more marked reduction in serum levels of testosterone (60\%, 35\%) and LH (44.08\%) as compared with the control. Vitamin E or C supplementation partially reversed the stress-induced reduction in serum testosterone level. However neither of the vitamins significantly altered LH level when compared to the stressed group.

Tables 2 and 3 present data of the effects of immobilization stress on the activity of the antioxidant enzymes; CAT and GST, in sera and testicular tissues of control and vitamin E- or C-treated rats.

Data revealed that acute stress reduced $(\mathrm{P}<0.005)$ CAT activity in serum $(24.3 \%)$ and testis $(60.21 \%)$ as compared with the control. Vitamin E supplementation significantly increased CAT activity in serum compared to the stressed group, but the values still lower than in the controls. Vitamin E and C supplementation partially reversed the stress induced reduction of CAT activity in both serum and testis.

Data also revealed that acute stress caused a reduction in the activity of GST in serum $(19.16 \%, \mathrm{P}<0.005)$ 
Table 1. Effect of immobilization stress on serum testosterone and LH concentrations of control and vitamin E- or vitamin C-treated rats.

\begin{tabular}{|c|c|c|c|c|}
\hline \multicolumn{2}{|c|}{ Experimental groups } & & Testosterone (ng/ml) & LH (ng/ml) \\
\hline \multicolumn{2}{|c|}{ Control } & $\begin{array}{c}\text { Mean } \pm \text { SEM } \\
\text { \%change }\end{array}$ & $4.01 \pm 0.07$ & $10.64 \pm 1.26$ \\
\hline \multirow{3}{*}{ Acute stress } & stress & $\begin{array}{c}\text { Mean } \pm \text { SEM } \\
\text { \%change }\end{array}$ & $\begin{array}{c}2.02 \pm 0.01^{\mathrm{a}^{* * * *}} \\
\quad-49.65\end{array}$ & $\begin{array}{c}7.28 \pm 0.12^{\mathrm{a}^{* *}} \\
-31.57\end{array}$ \\
\hline & Stress + Vit.E & $\begin{array}{l}\text { Mean } \pm \text { SEM } \\
\text { \%change }\end{array}$ & $\begin{array}{c}3.10 \pm 0.14^{\mathrm{a}, \mathrm{b}^{* * * *}} \\
-22.69\end{array}$ & $\begin{array}{c}7.85 \pm 0.23^{\mathrm{a}, \mathrm{b}^{*}} \\
-26.22\end{array}$ \\
\hline & Stress + Vit.C & $\begin{array}{c}\text { Mean } \pm \text { SEM } \\
\text { \%change }\end{array}$ & $\begin{array}{c}2.65 \pm 0.25^{\mathrm{a}^{* * *}, \mathrm{~b}^{*}} \\
-33.92\end{array}$ & $\begin{array}{c}7.55 \pm 0.01 \\
-29.04\end{array}$ \\
\hline \multirow{3}{*}{ Chronic stress } & Stress & $\begin{array}{c}\text { Mean } \pm \text { SEM } \\
\text { \%change }\end{array}$ & $\begin{array}{c}1.59 \pm 0.23^{\mathrm{a}^{* * * *}} \\
-60.35\end{array}$ & $\begin{array}{c}5.95 \pm 1.36^{\mathrm{a}^{* * *}} \\
-44.08\end{array}$ \\
\hline & Stress + Vit.E & $\begin{array}{c}\text { Mean } \pm \text { SEM } \\
\text { \%change }\end{array}$ & $\begin{array}{c}2.68 \pm 0.01^{\mathrm{a}, \mathrm{c}^{* * *}} \\
-33.17\end{array}$ & $\begin{array}{c}6.11 \pm 0.14^{\mathrm{a}^{* * *}} \\
-42.58\end{array}$ \\
\hline & Stress + Vit.C & $\begin{array}{l}\text { Mean } \pm \text { SEM } \\
\text { \%change }\end{array}$ & $\begin{array}{c}2.31 \pm 0.11^{\mathrm{a}^{* * *}, \mathrm{c}^{* *}} \\
\quad-42.39\end{array}$ & $\begin{array}{c}5.76 \pm 0.53^{\mathrm{a}^{* *}} \\
-45.87\end{array}$ \\
\hline
\end{tabular}

The results are given as mean \pm SEM for 10 rats. The percentage of change is compared with the control. Means within a category in the same column with different superscripts are significantly different $\left(\mathrm{P}<0.05=\right.$ significant $^{*}, \mathrm{P}<0.01=$ highly significant ${ }^{* *}, \mathrm{P}<0.005$ very highly significant ${ }^{* * * *}$ ).

Table 2. Effect of immobilization stress on the activity of Catalase (CAT) in serum and testis of control and vitamin E- or vitamin C-treated rats.

\begin{tabular}{|c|c|c|c|c|}
\hline \multirow{2}{*}{\multicolumn{2}{|c|}{ Experimental groups }} & & \multicolumn{2}{|c|}{ Catalase (CAT) } \\
\hline & & & Serum (U/L) & Testis (U/mg) \\
\hline \multicolumn{2}{|c|}{ Control I } & $\begin{array}{l}\text { Mean } \pm \text { SEM } \\
\text { \%change }\end{array}$ & $334.7 \pm 1.42$ & $8.015 \pm 0.05$ \\
\hline \multirow{3}{*}{ Acute stress } & Stress & $\begin{array}{l}\text { Mean } \pm \text { SEM } \\
\text { \%change }\end{array}$ & $\begin{array}{c}252.93 \pm 1.9^{\mathrm{a}^{* * *}} \\
24.43\end{array}$ & $\begin{array}{c}3.19 \pm 0.14^{\mathrm{a}^{* * * *}} \\
-60.21\end{array}$ \\
\hline & Stress + Vit.E & $\begin{array}{l}\text { Mean } \pm \text { SEM } \\
\text { \%change }\end{array}$ & $\begin{array}{c}305.68 \pm 1.88^{\mathrm{a}, \mathrm{b}^{* * *}} \\
-8.67\end{array}$ & $\begin{array}{c}6.74 \pm 0.93^{\mathrm{b}^{* *}} \\
-15.91\end{array}$ \\
\hline & Stress + Vit.C & $\begin{array}{l}\text { Mean } \pm \text { SEM } \\
\text { \%change }\end{array}$ & $\begin{array}{c}279.87 \pm 2.52^{\mathrm{a}, \mathrm{b}^{* * * *}} \\
-16.38\end{array}$ & $\begin{array}{c}5.48 \pm 0.13^{\mathrm{a}, \mathrm{b}^{* * * *}} \\
-31.63\end{array}$ \\
\hline \multirow{3}{*}{ Chronic stress } & Stress & $\begin{array}{l}\text { Mean } \pm \text { SEM } \\
\text { \%change }\end{array}$ & $\begin{array}{c}239.38 \pm 2.88^{\mathrm{a}^{* * * *}} \\
-28.48\end{array}$ & $\begin{array}{c}2.32 \pm 0.106^{\mathrm{a}^{* * * *}} \\
-71.05\end{array}$ \\
\hline & Stress + Vit.E & $\begin{array}{l}\text { Mean } \pm \text { SEM } \\
\text { \%change }\end{array}$ & $\begin{array}{c}300.38 \pm 3.03^{\mathrm{a}, \mathrm{c}^{* * *}} \\
-10.25\end{array}$ & $\begin{array}{c}6.24 \pm 0.11^{\mathrm{a}, \mathrm{c}^{* * *}} \\
-22.15\end{array}$ \\
\hline & Stress + Vit.C & $\begin{array}{l}\text { Mean } \pm \text { SEM } \\
\text { \%change }\end{array}$ & $\begin{array}{c}266.73 \pm 1.68^{\mathrm{a}, \mathrm{c}^{* * * *}} \\
-20.31\end{array}$ & $\begin{array}{c}4.95 \pm 0.057^{\mathrm{a}, \mathrm{c}^{* * * *}} \\
-38.24\end{array}$ \\
\hline
\end{tabular}

The results are given as the mean \pm SEM for 10 rats. The percentage of change is compared with the control. Means within a category in the same column with different superscripts are significantly different $(\mathrm{P}<0.05=$ significant*, $\mathrm{P}<0.01=$ highly significant ${ }^{* *}, \mathrm{P}<0.005$ very highly significant ${ }^{* * *}$ ).

and testis $(47.27 \%, \mathrm{P}<0.005)$ compared with the control. Vitamin E or C treatment significantly increased GST activity in serum and testis compared to the stressed group, but with values still lower than the control.

Chronic stress resulted in significant $(\mathrm{P}<0.005)$ and more marked reduction in the activities of CAT and GST in serum (28.48\% and 33.75\% respectively) and testis (71.05\% and $54.76 \%$ respectively) compared with the control. Vitamin E or C treatment increased $(\mathrm{P}<0.005)$ the activities of both enzymes in serum and testis compared to the stressed group, but with values still lower than the control.

Collectively, in both acute and chronic-stressed groups, vitamin E supplementation was more effective in reversing the stress-induced inhibition of CAT and GST activities in serum and testis.

As shown in Table 4, acute stress increased malondialdehyde (MDA) concentration in serum $(77.97 \%, \mathrm{P}<$ $0.005)$ and testis $(65.31 \%, \mathrm{P}<0.01)$ compared to the control. Vitamin E supplementation restored MDA concentration in serum and testis to nearly control levels. Vitamin C significantly decreased MDA concentration in 
Table 3. Effect of immobilization stress on the activity of Glutathione S-transferase (GST) in serum and testis of control vitamin E- or vitamin C-treated rats.

\begin{tabular}{|c|c|c|c|c|}
\hline \multirow{2}{*}{\multicolumn{2}{|c|}{ Experimental groups }} & & \multicolumn{2}{|c|}{ Glutathione S-transferase (GST) } \\
\hline & & & Serum (U/L) & Testis (U/mg) \\
\hline \multicolumn{2}{|c|}{ Control I } & $\begin{array}{c}\text { Mean } \pm \text { SEM } \\
\text { \%change }\end{array}$ & $483.35 \pm 2.35$ & $249.37 \pm 0.87$ \\
\hline \multirow{3}{*}{ Acute stress } & Stress & $\begin{array}{l}\text { Mean } \pm \text { SEM } \\
\text { \%change }\end{array}$ & $\begin{array}{c}390.75 \pm 2.48^{\mathrm{a}^{* * * *}} \\
-19.16\end{array}$ & $\begin{array}{c}131.50 \pm 1.58^{\mathrm{a}^{* * *}} \\
-47.27\end{array}$ \\
\hline & Stress + Vit.E & $\begin{array}{c}\text { Mean } \pm \text { SEM } \\
\text { \%change }\end{array}$ & $\begin{array}{c}441.06 \pm 1.92^{\mathrm{a}, \mathrm{b} * * *} \\
-8.75\end{array}$ & $\begin{array}{c}226.06 \pm 1.91^{\mathrm{ab} \mathrm{b}^{* * *}} \\
-9.35\end{array}$ \\
\hline & Stress + Vit.C & $\begin{array}{c}\text { Mean } \pm \text { SEM } \\
\text { \%change }\end{array}$ & $\begin{array}{c}419.49 \pm 1.91^{\mathrm{a}, \mathrm{b} * * *} \\
-13.21\end{array}$ & $\begin{array}{c}205.12 \pm 2.07^{\mathrm{a}, \mathrm{b}^{* * * *}} \\
-17.74\end{array}$ \\
\hline \multirow{3}{*}{ Chronic stress } & Stress & $\begin{array}{c}\text { Mean } \pm \text { SEM } \\
\text { \%change }\end{array}$ & $\begin{array}{c}320.23 \pm 2.13^{\mathrm{a}^{* * * *}} \\
-33.75\end{array}$ & $\begin{array}{c}112.81 \pm 2.04^{\mathrm{a}^{* * *}} \\
-54.76\end{array}$ \\
\hline & Stress + Vit.E & $\begin{array}{l}\text { Mean } \pm \text { SEM } \\
\text { \%change }\end{array}$ & $\begin{array}{c}419.60 \pm 1.32^{\mathrm{a}, \mathrm{c}^{* * * *}} \\
-13.19\end{array}$ & $\begin{array}{c}196.62 \pm 2.42^{\mathrm{a}, \mathrm{c}^{* * *}} \\
-21.15\end{array}$ \\
\hline & Stress + Vit.C & $\begin{array}{l}\text { Mean } \pm \text { SEM } \\
\text { \%change }\end{array}$ & $\begin{array}{c}381.69 \pm 2.12^{\mathrm{a}, \mathrm{c}^{* * * *}} \\
-21.03\end{array}$ & $\begin{array}{c}154.56 \pm 1.91^{\mathrm{a}, \mathrm{c}^{* * *}} \\
-38.02\end{array}$ \\
\hline
\end{tabular}

The results are given as the mean \pm SEM for 10 rats. The percentage of change is compared with the control. Means within a category in the same column with different superscripts are significantly different $\left(\mathrm{P}<0.05=\right.$ significant ${ }^{*}, \mathrm{P}<0.01=$ highly significant**, $\mathrm{P}<0.005$ very highly significant ${ }^{* * * *}$ ).

Table 4. Effect of immobilization stress on Malondialdehyde (MDA) concentration in serum and testis of control and vitamin E- or vitamin C-treated rat.

\begin{tabular}{|c|c|c|c|c|}
\hline \multirow{2}{*}{\multicolumn{2}{|c|}{ Experimental groups }} & \multicolumn{3}{|c|}{ Malondialdehyde (MDA) } \\
\hline & & & Serum (n mol/mL) & $\begin{array}{c}\text { Testis } \\
\text { (n mol/g fresh tissue) }\end{array}$ \\
\hline \multicolumn{2}{|c|}{ Control I } & $\begin{array}{l}\text { Mean } \pm \text { SEM } \\
\text { \%change }\end{array}$ & $49.38 \pm 3.9$ & $24.73 \pm 2.31$ \\
\hline \multirow{3}{*}{ Acute stress } & Stress & $\begin{array}{l}\text { Mean } \pm \text { SEM } \\
\text { \%change }\end{array}$ & $\begin{array}{l}87.88 \pm 7.2^{\mathrm{a}^{\mathrm{a**}}} \\
\quad+77.97\end{array}$ & $\begin{array}{l}40.88 \pm 3.50^{\mathrm{a**}} \\
\quad+65.31\end{array}$ \\
\hline & Stress + Vit.E & $\begin{array}{l}\text { Mean } \pm \text { SEM } \\
\text { \%change }\end{array}$ & $\begin{array}{l}55.28 \pm 5.6^{\mathrm{b}^{* * *}} \\
\quad+11.95\end{array}$ & $\begin{array}{l}28.29 \pm 1.91^{\mathrm{b}^{* * *}} \\
\quad+14.40\end{array}$ \\
\hline & Stress + Vit.C & $\begin{array}{l}\text { Mean } \pm \text { SEM } \\
\text { \%change }\end{array}$ & $\begin{array}{c}66.61 \pm 6.2^{\mathrm{a}, \mathrm{b}^{*}} \\
+34.89\end{array}$ & $\begin{array}{c}31.35 \pm 2.11^{\mathrm{a}, \mathrm{b}^{*}} \\
+26.77\end{array}$ \\
\hline \multirow{3}{*}{ Chronic stress } & Stress & $\begin{array}{c}\text { Mean } \pm \text { SEM } \\
\text { \%change }\end{array}$ & $\begin{array}{c}95.16 \pm 7.8^{\mathrm{a}^{* * * *}} \\
+92.71\end{array}$ & $\begin{array}{c}48.55 \pm 4.80^{\mathrm{a}^{* * *}} \\
+96.32\end{array}$ \\
\hline & Stress + Vit.E & $\begin{array}{l}\text { Mean } \pm \text { SEM } \\
\text { \%change }\end{array}$ & $\begin{array}{c}61.81 \pm 4.9^{\mathrm{a}^{*}, c^{* * * *}} \\
+25.17\end{array}$ & $\begin{array}{c}33.68 \pm 1.95^{\mathrm{a}, \mathrm{c}^{* *}} \\
+33.68\end{array}$ \\
\hline & Stress + Vit.C & $\begin{array}{c}\text { Mean } \pm \text { SEM } \\
\text { \%change }\end{array}$ & $\begin{array}{l}70.37 \pm 6.5^{\mathrm{a}^{* *}, \mathrm{c}^{*}} \\
+42.51\end{array}$ & $\begin{array}{c}35.93 \pm 2.06^{\mathrm{a}^{* *}, \mathrm{c}^{*}} \\
+45.29\end{array}$ \\
\hline
\end{tabular}

The results are given as the mean \pm SEM for 10 rats. The percentage of change is compared with the control. Means within a category in the same column with different superscripts are significantly different $\left(\mathrm{P}<0.05=\right.$ significant ${ }^{*}, \mathrm{P}<0.01=$ highly significant ${ }^{* *}, \mathrm{P}<0.005$ very highly significant ${ }^{* * *}$ ).

serum and testis compared to the stressed group; however the values were still higher than the control.

Chronic stress caused significant and more marked increase in MDA concentration in serum $(92.71 \%, \mathrm{P}<$ 0.005) and testis $(96.32 \%, \mathrm{P}<0.005)$ compared to the control. Vitamin $\mathrm{E}$ or $\mathrm{C}$ supplementation decreased $(\mathrm{P}<$ 0.01) MDA concentration in serum and testis compared to the stressed group, with values still higher than the controls. Vitamin E was more effective than vitamin C in modulating MDA levels in serum and testis.

\section{Discussion}

The results of the present study revealed that acute and chronic immobilization stress caused significant decrease 
in serum testosterone in mole rats. This finding is consistent with number of studies in humans and animals which confirm the inhibitory role of different stressors on the hormonal function of the testis by decreasing the testosterone level in the blood [2] [3].

This study also resulted in a significant stress-induced reduction in serum LH level, which might be responsible for the decline in testosterone concentration. Previous studies indicated that many stressors decrease LH and consequently testosterone levels by inhibiting LHRH synthesis and release from the hypothalamus [1]. Such stress-induced inhibition of the hypothalamic-pituitary-gonad (HPG) axis may be mediated by corticotropin releasing factor (CRF) and endogenous opioids, mainly $\beta$-endorphins which are known to be released from the hypothalamus in response to stress [25]. It has been shown that both CRF and $\beta$-endorphins can exert their effects on the HPG axis by inhibiting LH-RH release from the hypothalamus [26], inhibiting LH release from the pituitary [27], and inhibiting testosterone synthesis directly in Leydig cells [28], thus decreasing testosterone levels in the blood circulation.

It is assumed that endogenous opioids could be participating in the effects caused by stress on testosterone secretion. The recent study of Retana-Marquez et al. [3] indicated that the decrease in testosterone secretion due to stress was attenuated with the opioid antagonist "Naltrexone".

Excessive secretion of glucocorticoids during stress could be another mechanism for the stress-induced decline in testosterone level in this study. Glucocorticoids directly inhibit Leydig cell function through a glucocorticoid receptor-mediated pathway [29]. It has been shown that glucocorticoids inhibit testosterone synthesis by inhibiting some of the enzymes involved in testicular steroidogenesis, such as NADPH-P450 reductase, P450c 17 (17 $\alpha$-hydroxylase and 17, 20-lyase) and 3 $\beta$-hydroxysteroid dehydrogenase [29].

In addition, excessive exposure to glucocorticoids initiates apoptosis in Leydig cells, potentially contributing to the suppression of testosterone level caused by the decline in steroidogenic capacity [1] [30].

Moreover, deterioration of the blood flow in the testis might contribute to the stress-induced reduction in testosterone level [31]. It is known that stimulation of the sympathetic nerves of the testis or injection of catecholamines causes vasoconstriction and reduces blood flow in the testes in various mammals [31].

Likewise, data of the current study revealed significant reduction in the activity of the antioxidant enzymes; CAT and GST in sera and testes of rats after exposure to immobilization stress. This effect was more pronounced in case of chronic stress.

Both CAT and GST are important scavenger enzymes against free radicals [11] [12]. CAT acts synergistically with superoxide dismutase (SOD) to remove superoxide anions generated by NADPH-oxidase in the cells. They play an important role in decreasing oxidative stress and membrane lipid peroxidation [32]. Also, GST plays important roles in the detoxification of reactive lipid peroxides [12].

The results of the present study also showed an increase in Malondialdehyde (MDA) concentrations in serum and testis of rats after exposure to acute and chronic immobilization stress. This indicates increased lipid peroxidation as MDA results from the breakdown of polyunsaturated fatty acids and considered as one of the manifestations of free radicals-induced cytotoxicity [33] [34].

Thus, the reduction in the activity of CAT and GST as antioxidant enzymes, together with the increase in MDA concentration indicate an increased production of free radicals and induction of oxidative stress in the immobilization stressed rats. This finding supports previous reports which proved that exposure to various stressors leads to oxidative stress and its consecutive structural and functional tissue damage as a result of increased formation of free radicals and reactive oxygen species (ROS) [35] [36]. It is well known that ROS are responsible for damaging almost all cellular macromolecules including membrane polyunsaturated fatty acids, carbohydrates, proteins and DNA, potentially causing impairment of cellular functions [8] [9]. Testicular membranes are rich in polyunsaturated fatty acids and therefore are susceptible to oxidative stress [10]. Testicular steroidogenesis is sensitive to free radicals and ROS and a correlation was noted between free radicals production and gonadal steroidogenesis [12]. In this concern, several lines of evidence have suggested that nitric oxide (NO) free radical mediates the stress-induced downregulation of testicular steroidogenesis [37].

Accordingly, oxidative stress could be considered a direct mechanism that mediated the downregulation of testicular steroidogenesis and reduction of testosterone level in immobilization stressed rats. Impairment of testicular steroidogenesis might coincide with inhibition of the steroidogenic enzyme activity by the generation of large amounts of ROS in testicular tissue [11]. Also the lipid peroxidation meiabolitc; MDA exerts detrimental effects on testicular steroidogenic enzyme activity [10]. Moreover, a confirmatory evidence for the inhibitory effect of oxidative stress on testicular steroidogenic enzyme activity has been provided by Tatjana et al. [37] 
who reported significant inhibition of testicular $3 \beta$-hydroxysteroid dehydrogenase, $17 \alpha$-hydroxylase/lyase (P450 C17) and NADPH-P450 reductase activities in immobilization stressed-rats. Also, in the study of Manna et al. [36] they reported that swimming exercise-induced oxidative stress in rats caused inhibition of the activities of testicular $3 \beta$-hydroxysteroid dehydrogenase and $17 \beta$-hydroxysteroid dehydrogenase.

The data obtained in the present study exhibited that supplementation with either $\alpha$-tocopherol or ascorbic acid partially reversed the stress-induced reduction of serum testosterone levels. Likewise, both vitamins also increased CAT and GST activities and significantly decreased MDA concentrations in serum and testis as compared with the stressed group, denoting less production of free radicals and lipid peroxidation. Such alleviation of oxidative stress could explain the partial restoration of testosterone serum levels in the supplemented groups.

The protective effect of $\alpha$-tocopherol and ascorbic acid may be attributed to their properties as chain-breaking antioxidants that prevent the propagation of free radical reaction and inhibit lipid peroxidation [10] [15]. They also elevate antioxidant enzymes activities [13] [14], and maintain the balance between antioxidants and oxidants in tissues [38] [39]. Besides, their protective effect from oxidative stress also depends on their role in stabilization of membrane structures [40] [41].

Moreover, apart from its antioxidative properties, $\alpha$-tocopherol has a direct stimulatory effect on enzymes of gonadal steroid biosynthesis, and may also exert some modulatory action on gonadotropin synthesis and secretion [42].

\section{Conclusion}

In conclusion, immobilization stress generates some metabolic and hormonal disorders in the body. These could be alleviated by administration of vitamin $\mathrm{E}$ and $\mathrm{C}$, which exhibited enhancement effects on the body. Further multidisciplinary studies are needed for monitoring various cellular mechanisms regulating coping for the stress process.

\section{References}

[1] Hardy, M.P., Gao, H.B., Dong, Q.G.R., Wang, Q. and Chai, W.R. (2005) Stress Hormone and Male Reproductive Function. Cell Tissue Research, 322, 147-153. http://dx.doi.org/10.1007/s00441-005-0006-2

[2] Razzoli, M., Roncari, E., Guidi, A., Carboni, L., Arban, R. and Gerrard, P. (2006) Conditioning Properties of Social Subordination in Rats: Behavioral and Biochemical Correlates of Anxiety. Hormone Behavior, 50, 245-251. http://dx.doi.org/10.1016/j.yhbeh.2006.03.007

[3] Retana-Marquez, S., Bonilla-Jaime, H., Vazquez-Palacio, G. and Martinez-Garcia, R. (2009) Naltrexone Effects on Male Sexual Behavior, Corticosterone, and Testosterone in Stressed Male Rats. Physiology and Behavior, 96, 333-342. http://dx.doi.org/10.1016/j.physbeh.2008.10.022

[4] Chichinadze, K. and Chichinadz, N. (2008) Stress-Induced Increase of Testosterone: Contribution of Social Status. Physiology and Behavior, 94, 595-603. http://dx.doi.org/10.1016/j.physbeh.2008.03.020

[5] Selvage, D.J. and Rivier, C. (2003) Importance of the Paraventricular Nucleus of the Hypothalamus as a Component of Neural Pathway between the Brain and the Testes That Modulates Testosterone Secretion Independently of the Pituitary. Endocrinology, 144, 594-598. http://dx.doi.org/10.1210/en.2002-220781

[6] Wingfield, J.C. and Sapolsky, R.M. (2003) Reproduction and Resistance to Stress: When and How. Journal of Neuroendocrinology, 15, 711-724. http://dx.doi.org/10.1046/j.1365-2826.2003.01033.x

[7] Hu, Y., Cardounel, A., Gursoy, E., Anderson, P. and Kalimi, M. (2000) Anti-Stress Effects of Dehydroepiandrosterone: Protection of Rats against Repeated Immobilization Stress-Induced Weight Loss, Glucocorticoid Receptor Production, and Lipid Peroxidation. Biochemistry and Pharmacology, 59, 753-762. http://dx.doi.org/10.1016/S0006-2952(99)00385-8

[8] Chih, Y.A. and Mao, T.I. (2002) Oxidative Stress in Rats with Heatstroke-Induced Cerebral Ischaemia. American Heart Association Inc., 33, 790.

[9] Juliet, M.T. (2004) Impact of Oxidative Stress on Neuronal Survival. Clinical and Experimental Pharmacology and Physiology, 31, 397. http://dx.doi.org/10.1111/j.1440-1681.2004.04017.x

[10] Ghosh, D., Das, U.B., Mallick, M. and Debnath, I. (2002) Testicular Gametogenic and Steroidogenic Activities in Cyclophosphamide Treated Rat: A Correlative Study with Testicular Oxidative Stress. Drug Chemistry and Toxicology, 25, 28-292. http://dx.doi.org/10.1081/DCT-120005891

[11] Jana, K., Samanta, P.K. and Ghosh, D. (2002) Dose Dependent Response to Intra Testicular Injection of Calcium Chloride for Induction of Chemosterilization in Adult Albino Rats. Veterinary Research Communication, 26, 651-673. 
http://dx.doi.org/10.1023/A:1020976905746

[12] Manna, I., Iana, K. and Samanta, P.K. (2003) Effect of Exercise-Induced Testicular Gametogenic and Steroidogenic Disorders in Nature Wistar Strain Rats: A Correlative Approach to Oxidative Stress. Acta Physiologica-Scandaniva, 178, 33-40.

[13] Hsu, H.G., Lee, Y.T. and Chen, M.F. (2002) Effect of Fish Oil and Vitamin E on the Antioxidant Defense System in Diet-Induced Hypercholesterolemic Rabbits. Prostaglandins and other Lipids Mediators, 66, 99-108.

[14] Muthuvel, R., Venkataraman, P., Stanley, A. and Aruna Karan, I. (2006) Antioxidant Effect of Ascorbic Acid on PCB (Aroclor 1254) Induced Oxidative Stress in Hypothalamus of Albino Rat. Clinical Chemistry Acta, 365, $297-303$. http://dx.doi.org/10.1016/j.cca.2005.09.006

[15] Yoon, H.K., Cheol, K.H., Moon, K.C., Kimim, S.Y., Sung, Y.Y., Seok, M.K. and Tae, B.S. (2006) Total Peroxyl Radicals-Trapping Ability and Antioxidant Vitamins of the Umbilical Vein Plasma and the Placenta in Pre-Eclampsia. Journal of Obstetrics and Gynaecobgy Research, 32, 32-41. http://dx.doi.org/10.1111/j.1447-0756.2006.00348.x

[16] Ihara, Y., Yamada, Y., Toyokuni, S., Miyawaki, K. and Ban, N.(2000) Antioxidant Alpha-Tocopherol Ameliorates Glycemic Control of GK Rats, a Model of Type 2 Diabetes. FEBS Letters, 473, 24-26. http://dx.doi.org/10.1016/S0014-5793(00)01489-7

[17] Mahfouz, M.M. and Kummerow, F.A. (2004) Vitamin C or Vitamin B6 Supplementation Prevent the Oxidative Stress and Decrease of Prostacyclin Generation in Homocysteinemic Rats. The International Journal of Biochemistry and Cell Biology, 36, 1919-1932. http://dx.doi.org/10.1016/j.biocel.2004.01.028

[18] Lopez-Calderon, A., Arznavarreta, C., Calderon, M.D., Tresguerres, J.A.F. and Gonzalez-Quijano, M.I. (1989) Role of the Adrenal Cortex in Chronic Stress-Induced Inhibition of Prolactin Secretion in Male Rats. Journal of Endocrinology, 120, 269-273. http://dx.doi.org/10.1677/joe.0.1200269

[19] Trachtenberg, J. (1987) Experimental Treatment of Prostatic Cancer by Intermittent Hormonal Therapy. Journal of Urology, 137, 785-788.

[20] Santner, S.J., Santen, R.J., Kulin, H.E. and Demers, I.M. (1981) A Model for Validation of Radioimmunoassay Kit Reagent: Measurement of Follitropin and Lutropin in Blood and Urine. Clinical Chemistry, 27, 1892-1895.

[21] Aebi, H. (1984) Catalse in Vitro. Methods in Enzymology, 105, 121-126. http://dx.doi.org/10.1016/S0076-6879(84)05016-3

[22] Habig, W., Pabst, M. and Jakoby, W. (1974) Glutathione-S-Transferase: The First Enzymatic Step in Mercapturic Acid Formation. The Journal of Biological Chemistry, 249, 7130-7139.

[23] OhKawa, H., Ohishi, W. and Yagi, K. (1979) Assay of Lipid Peroxides in Animal Tissues by Thiobarbituric Acid Reaction. Analytical Biochemistry, 95, 351-358. http://dx.doi.org/10.1016/0003-2697(79)90738-3

[24] Steel, R.G.D. and Torrie, J.H. (1980) Principles and Procedures of Statistics. McGraw-Hill Book Company Inc., New York.

[25] Vaccarino, A.L. and Kastin, A.J. (2000) Endogenous Opiates. Peptides, 21, 1975-2034. http://dx.doi.org/10.1016/S0196-9781(00)00345-4

[26] Bidzinska, B., Petraglia, F., Angioni, S., Genazzan, A.D., Riscuolo, M. and Ficarra, G. (1993) Effect of Different Chronic Intermittent Stressors and Acetyl-Carntine on Hypothalamic Beta-Endorphin and GnRH and on Plasma Testosterone Levels in Male Rats. Neuroendocrinology, 57, 985-990. http://dx.doi.org/10.1159/000126489

[27] Maric, D., Kostic, T. and Kovacevic, R. (1996) Effects of Acute and Chronic Immobilization on Rat Leydig Cell Steroidogenesis. The Journal of Steroid Biochemistry and Molecular Biology, 58, 351-355. http://dx.doi.org/10.1016/0960-0760(96)00044-1

[28] Kostic, T., Andric, S., Maric, D. and Kovacevic, R. (1998) The Effect of Acute Stress and Opioid Antagonist on the Activity of NADPH-P450 Reductase in Rat Leydig Cells. The Journal of Steroid Biochemistry and Molecular Biology, 66, 51-54. http://dx.doi.org/10.1016/S0960-0760(98)00003-X

[29] Dong, Q., Salva, A., Sottas, C.M., Niu, E., Holmes, M. and Hardy, M.P. (2004) Rapid Glucocorticoid Mediation of Suppressed Testosterone Biosynthesis in Male Mice Subjected to Immobilization. Journal of Andrology, 25, 973-981.

[30] Gao, H.B., Tong, M.H., Hu, Y.Q., Guo, Q.S.G. and Hardy, M.P. (2002) Glucocorticoid Induces Apoptosis in Rat Leydig Cells. Endocrinology, 143, 130-138. http://dx.doi.org/10.1210/endo.143.1.8604

[31] Kraut, A., Barbiro-Mchaely, E. and Mayevsky, A. (2004) Differential Effects of Norepinephrine on Brain and Other Less Vital Organs Detected by a Multisite Multiparametric Monitoring System. Medical Science Monitor, 10, BR215-BR220.

[32] Powers, S.K., Ji, L.L. and Leeuwenburgh, C. (1999) Exercise Training-Induced Alterations in Skeletal Muscle Antioxidant Capacity: A Brief Review. Medicine \& Science in Sports \& Exercise, 31, 987-997. http://dx.doi.org/10.1097/00005768-199907000-00011

[33] Dibnath, D. and Mandal, T.K. (2000) Study of Quinalphos (An Environmental Oestrogenic Insecticide) Formulation 
(Ekalux 25 E.C.)-Induced Damage of the Testicular Tissues and Antioxidant Defence Systems in Sprague-Dewley Albino Rats. Journal of Applied Toxicology, 20, 197-204. http://dx.doi.org/10.1002/(SICI)1099-1263(200005/06)20:3<197::AID-JAT634>3.0.CO;2-7

[34] Ojo, O.O., Kabutu, F.R., Bello, M. and Babayo, U. (2006) Inhibition of Paracetamol-Induced Oxidative Stress in Rats by Extracts of Lemongrass (Cymbropogon Citrates) and Free Tea (Camellia Sinensis) in Rats. African Journal of Biotechnology, 5, 1227-1232.

[35] Madrigal, J.L., Olivenza, R., Moro, M.A., Lizasoain, I., Lorenzo, R., Rodrigo, J. and Leza, J.C. (2001) Glutathione Depletion, Lipid Peroxidation and Mitochondrial Dysfunction Are Induced by Chronic Stress in Rat Brain. Neuropsychopharmacology, 24, 420-429.

[36] Manna, I., Jana, K. and Samanta, P.K. (2004) Intensive Swimming Exercise-Induced Oxidative Stress and Reproductive Dysfunction in Male Wistar Rats: Protective Role of $\alpha$-Tocopherol Succinate. Canadian Journal of Applied Physiology, 29, 172-185. http://dx.doi.org/10.1139/h04-013

[37] Tatjana, S.K., Silvana, A.A., Desanka, M. and Radmila, Z.K. (2000) Inhibitory Effects of Stress-Activated Nitric Oxide on Antioxidant Enzymes and Testicular Steroidogenesis. Journal of Steroid Biochemistry \& Molecular Biology, 75, 299-306. http://dx.doi.org/10.1016/S0960-0760(00)00185-0

[38] Atalay, M., Laaksonen, D.E., Khanna, S., Kaliste-Korhonen, E., Hanninen, O. and Sen, C.K. (2000) Vitamin E Regulates Changes in Tissue Antioxidants Induced by Fish Oil and Acute Exercise. Medicine and Science in Sports and Exercise, 32, 601-607. http://dx.doi.org/10.1097/00005768-200003000-00008

[39] Soltys, K., Dikdan, G. and Koneru, B. (2001) Oxidative Stress in Fatty Livers of Obese Zucker Rats: Rapid Amelioration and Improved Tolerance to Warm Ischaemia with Tocopherol. Hepatology, 34, 13-18. http://dx.doi.org/10.1053/jhep.2001.25452

[40] Venditti, P., Masulla, P., DiMeo, S. and Agnisola, C. (1999) Protection against Ischemia Reperfusion Induced Oxidative Stress by Vitamin E Treatment. Archive of Physiology and Biochemistry, 107, 27-34. http://dx.doi.org/10.1076/apab.107.1.27.4355

[41] Debjyoti, S., Hanjit, S., Neelam, A., Siddarth, M. and Kala, V. (2003) Lipid Peroxidation and Vitamin Status in Gestational Diabetes Mellitus. Journal Obstetrics and Gynaecology Research, 29, 300-304. http://dx.doi.org/10.1046/j.1341-8076.2003.00127.x

[42] Das, P. and Chowdhury, M. (1999) Vitamin E-Deficiency Induced Changes in Ovary and Uterus. Molecular and Cellular Biochemistry, 198, 151-156. 